\title{
Clinical View of COVID-19 Impact on Children and Adolescents
}

\author{
(1) Ernest Herbert, ${ }^{1}$ ( Dominique Fournier ${ }^{2}$
}

'Ashfield Healthcare Ltd, United Kingdom

${ }^{2}$ Institut Universitaire de Cardiologie et de pneumologie de Québec - Université Laval, Canada

\section{ABSTRACT}

The first case of coronavirus disease (COVID-19) infection was on 17 November 2019 according to Chinese government sources. COVID-19 symptoms among children seem to be milder compared with adults. Moreover, whether certain groups of children, for instance, those with comorbidities, may be at higher risk of more severe illness is unknown. Emerging data on the spread of COVID-19 in children have not been presented in detail. Due to its long incubation period (2-14 days) and because children can be asymptomatic or present mild, nonspecific symptoms, everyone should be considered potential COVID-19 carriers unless proven otherwise. This article is aimed at highlighting vertical transmission, clinical presentation, pediatric inflammatory multisystem syndrome and common COVID-19 features among children/adolescents and its impact on them. Pediatric patients with COVID-19 may not have fever or cough. However, social distancing and everyday preventive measures are necessary as those with less serious illness and others without symptoms are likely to play a major role in disease transmission.

Keywords: COVID-19 pandemic, infectious disease transmission, vertical infectious disease transmission, pathological conditions, signs and symptoms, pediatrics

\section{INTRODUCTION}

From 31 December 2019, to 27 June 2020, more than 10 million people worldwide have been infected with coronavirus disease (COVID-19) and more than 500,000 mortalities are currently recorded with the number increasing daily. ${ }^{[1]} \mathrm{Half}$ of these cases have been reported from the US and the other half from the European Union/European Economic Area countries, UK, and the rising rate currently in Brazil. ${ }^{[2]}$

The transmission rate and increasing fatalities associated with COVID-19 are alarming on a global scale. ${ }^{[3]}$ Moreover, limited reports in the pediatric population and the adolescence are available. Although children and young adults are potentially susceptible to COVID-19 infection, attention has been drawn mainly to their major role in influencing spread and community transmission rather than infection severity and consequential mortalities. Furthermore, children, teens, and young adults with heart disease are at greater risk of severe COVID-19 complications than previously thought and those with comorbidities face a bigger one.

Children are affected by COVID-19. ${ }^{[4]}$ However, data, largely from China, indicated that they are less likely to be affected than adults. The youngest patient identified was 28 days old with several neonates cases. The World Health Organization-China Joint Mission Report on 
COVID-19 concludes that "we cannot determine the extent of infection among children, what role children play in transmission, whether children are less susceptible or if they present differently clinically."[5]

The COVID-19 pandemic has challenged healthcare workers worldwide in such a way that they are trying to provide a standard of care and at the same time deal with community health issues. ${ }^{[6]}$ The appropriate response depends on patient populations, specialties, practice setting and availability of resources locally. For example, telemedicine with video links and zoom meeting appointments have been used by providers as strategies to continue caring for patients while reducing the risks of COVID-19 transmission. Telemedicine is defined by the Centers for Medicare and Medicaid Services as a two-way process where live communication is applied between the patient and the provider at a distant site including audio and video equipment. The scramble to care for children and young adolescents amid the COVID-19 pandemic raises questions about the quality of care, telemedicine limitations, internet connections and challenges with confidentiality of the patients involved, especially with certain diagnostic examinations. ${ }^{[7]}$

\section{Vertical Transmission}

With the increasing spread of COVID-19, more infections among pregnant women are likely to be noticed. ${ }^{[8]}$ Thus, whether COVID-19 infection could contribute to the risk of miscarriage, stillbirth, preterm delivery, fetal tachycardia and distress is yet unknown. Chances are that this infection in pregnant women may heighten the risk of maternal mortality. The clinical presentation and placental pathologies of three infected women have been reported. Chen et al. also found that infections among women in late-stage pregnancy were similar to those who are not pregnant and no severe specific conditions were noted among the three identified cases.

Maternal infection during the third trimester may not or very rarely takes place. The consequences of the COVID-19 pandemic on women during early pregnancy remain unknown. However, precautionary measures, just like any other member of the public, have to be taken to avoid being infected by COVID-19. For instance, a pregnant nurse in the UK with deteriorated health condition due to COVID-19 infection tragically expired during the course following cesarean section. Two maternal mortalities due to $\mathrm{CO}-$ VID-19 have also been reported in Iran.$^{[9]}$ Future work may clarify whether the virus may be transmitted to the fetus or whether any malformations while growing, fetal organ disruption, early loss, abortions and any associated premature labor exist.
All ages are at risk of this viral infection. ${ }^{[10,11]}$ Intrauterine transmission, although not likely, but cannot be excluded, exists as reports of perinatal transmission are emerging. ${ }^{[12,13]}$ However, cases of vaginal deliveries without perinatal transmission have been reported. ${ }^{[14,15]}$ Some neonates were not infected with COVID-19 although some had perinatal complications, as shown in a study involving 30 neonates being delivered from mothers with COVID-19. However, the placenta of the neonates with complications tested positive for COVID-19. ${ }^{[16]}$

\section{Clinical Presentation}

The virus has been identified in the respiratory tract samples 1-2 days before symptom onset, and can persist for up to 8 days after their first appearance in mild cases, and up to longer periods when the infection becomes severe, peaking after the second week. ${ }^{[17]}$ The high viral load close to symptom onset indicates that COVID-19 can be easily transmitted at the early stage of infection. ${ }^{[18]}$ Moreover, viral RNA has been detected in feces, whole blood, serum, saliva, nasopharyngeal specimens and urine..$^{[19-24]}$

The median COVID-19 incubation period according to the current estimates is 5-6 days (range 1-14 days). Moreover, Lauer et al. noted that compatible symptoms will appear within 11.5 days in $97.5 \%$ of COVID-19-infected people, and it is in accordance with the US Department of Health and Human Services Centers for Disease Control and Prevention (Table 1). ${ }^{[25,26]}$ Asymptomatic infection at the time of laboratory confirmation has been reported from different settings. ${ }^{[27-30]}$ Some of the affected individuals developed some symptoms at a later stage. However, the proportion is not yet fully understood. ${ }^{[31]}$ The typical age range and the corresponding pediatric cases from different countries are shown in Table $2 .^{[32,33]}$

Table 1. Signs and symptoms of COVID-19 among paediatric patients with laboratory-confirmed cases

n (\%)

Fever, cough or shortness of breath

$213(73)$

Fever

$163(56)$

Cough

$158(54)$

Shortness of breath

Myalgia

Runny nose

$21(7.2)$

Sore throat

$71(24)$

Headache

Nausea/vomiting

Abdominal pain

$17(5.8)$

Diarrhoea

$37(13)$ 
Table 2. Typical age ranges of confirmed paediatric cases on COVID-19 and list of countries with reported infections

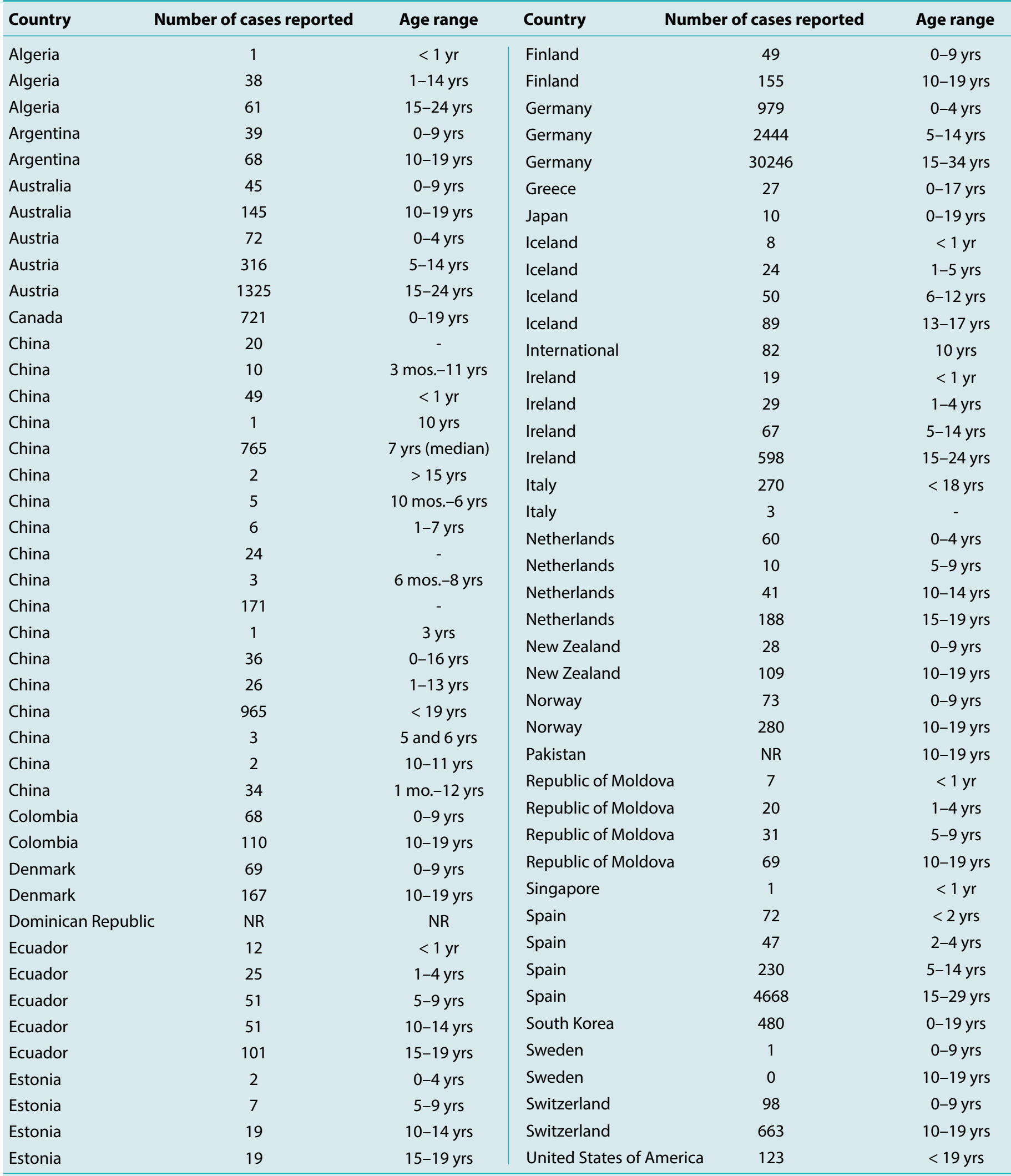

NR: Not reported. 


\section{The Impact of COVID-19 on Children and Young People}

The pandemic brought not only mortalities from the viral infection but also unbearable psychological and emotional trauma to most people worldwide. The continuous spread of the pandemic; strict isolation measures; and delays in starting schools, colleges, and universities worldwide are expected to influence the mental health of pupils, college and higher-degree students. Studies have reported that public health emergencies have psychological effects on college students expressed as anxiety, fear, worry and others. ${ }^{[34]}$ According to Cao et al., about $24.9 \%$ of these students have experienced anxiety because of the COVID-19 outbreak. ${ }^{[35]}$ The protective factors against anxiety include living in urban areas, living with parents and having a stable family source of income. However, having a relative or an acquaintance infected with COVID-19 was an independent risk factor for experienced anxiety. Other related COVID-19 stressors involved economic effects on daily life, academic delays and limiting social interactions with peers and colleagues. Certain groups of children, depending on their ages, may not even understand what a pandemic is and talk less regarding the health implications. ${ }^{[36,37]}$

The pandemic has disrupted the life of every child and the facets of living in all affected countries. ${ }^{[38]}$ The disease is not only an unprecedented public health emergency but also a challenge to society and the economy beyond unimaginable proportions. Thus, governments and decision-makers at every level face a colossal challenge. School closures, while an important way to stave off the spread of COVID-19, could result in increased social isolation for young people. Although many schools are providing online education, children whose families cannot afford access to laptops, telephones or adequate internet/phone connections are likely to miss out on crucial learning. For a very young person who cannot access any such e-learning that schools are providing, an added risk of stigma or shame exists.

Children with long-term physical and health conditions may feel less confident ineffectively managing them during the crisis. ${ }^{[39]}$ Concerns and worries about the virus will likely impact those living with anxiety and depression. For those with hyperactivity conditions or attention deficit hyperactivity disorder and autism spectrum disorders, having their movements restricted at home and even outside may be quite challenging. Moreover, children with special educational needs and learning disabilities may require support to adjust to habitual activities and understand what is going on, compared with what used to be normal or routine.

Practicing social distancing or even being self-isolated will reduce choices. Thus, autonomous children and young people are going to have no control over their lives. The consequences of COVID-19 on society at large will be in long-term. ${ }^{[40]}$ Alongside worries about long-term health implications, important positive outcomes may exist as young people may respond by taking up careers in healthcare, the sciences and public health.

\section{Pediatric Inflammatory Multisystem Syndrome and Adolescents Linked with COVID-19}

On 12 May 2020, 102 children in New York State have had virus-related symptoms in the heart similar to those of Kawasaki and toxic shock-like syndrome. Consequently, three have expired. ${ }^{[41]}$ Similarly, the European Center for Disease Prevention and Control noted 224 cases suffering from the same illness across Europe on this unique day. ${ }^{[42]}$ This new condition has been termed pediatric inflammatory multisystem syndrome (PIMS), whose primary symptoms include persistent fever, extreme systemic inflammation and one or more malfunctioning organs. However, its mechanisms remain unclear. A team from Bergamo, Italy, reported a 30-fold increase in the cases of Kawasaki disease and 10 patients with Kawasaki-like syndrome. Furthermore, eight of the patients tested positive for immunoglobulin $\mathrm{G}$ and M. ${ }^{[43]}$

Eight children in London, UK, were reported to have a hyperinflammatory shock with characteristic features typical of Kawasaki disease or toxic shock syndrome. All eight children were positive for COVID-19 antibodies. ${ }^{[44]}$ In another development, 125 cases of PIMS have been documented between 1 March and 12 May and 65 of these PIMS cases were positive for COVID-19 (Table 3). ${ }^{[42]}$ These reports have shown that PIMS symptoms overlap with the Kawasaki disease and affected patients also exhibit some features not commonly associated with the latter ${ }^{[45]}$ Compared with Kawasaki disease, Italian pediatricians have noticed that patients who had Kawasaki disease-linked COVID-19 were older with gastrointestinal, meningeal, leukopenia, marked lymphopenia, thrombocytopenia symptoms, elevated ferritin levels and features of myocarditis. ${ }^{[43]}$ High incidences of myocarditis and cardiac disorders have been linked with Kawasaki disease-COVID-19 cases. ${ }^{[44,46]}$ The clinical presentation of patients with PIMS suggests that many had experienced mild COVID-19 symptoms after contact with family members who had then tested positive.

This pandemic has new developments (e.g., the emergence of PIMS and having clinical features that are different from Kawasaki disease). ${ }^{[45]}$ As crucial characteristics of PIMS remains unknown, future research work will need a multidisciplinary approach which will include pediatricians, internists, rheumatologists, immunologists, geneticists, infectiologists, cardiologists and epidemiologists. 
Table 3. Distribution and clinical presentation of reported PIMS associated with COVID-19 in EU/EEA countries

\begin{tabular}{|c|c|c|c|c|c|c|}
\hline Country & $\begin{array}{l}\text { Date of reporting } \\
\text { in } 2020\end{array}$ & $\begin{array}{c}\text { Median age } \\
\text { in years (range) }\end{array}$ & $\begin{array}{c}\text { COVID-19 } \\
\text { infection status }\end{array}$ & $\begin{array}{c}\text { Other associated } \\
\text { pathogens }\end{array}$ & $\begin{array}{c}\text { Number of } \\
\text { reported cases }\end{array}$ & Fatalities \\
\hline Austria & $29 / 4 / 2020$ & $11 \mathrm{yrs}$ & $\begin{array}{c}\text { COVID }-19+\text { before } \\
\text { deterioration of symptoms; } \\
\text { lgG }+2 \text { wks later }\end{array}$ & $\begin{array}{c}\text { Group A } \\
\text { streptococci }\end{array}$ & 1 & 0 \\
\hline Canada & $3 / 5 / 2020$ & NS & NS & NS & 12 & NS \\
\hline France & $14 / 5 / 2020$ & $<1-\geq 15$ yrs & COVID-19 positive & NS & 125 & 1 \\
\hline Germany & $11 / 5 / 2020$ & $8(3-14)$ yrs & COVID-19 positive & None & 5 & NS \\
\hline $\begin{array}{l}\text { Greece } \\
\text { negative }\end{array}$ & $11 / 5 / 2020$ & NS & COVID-19 & NS & 1 & NS \\
\hline Italy & $13 / 5 / 2020$ & $7.5 \mathrm{yrs}$ & $\begin{array}{c}\text { Positive, but } 1 \text { test was } \\
\text { inconclusive after a high } \\
\text { dose of IVIG }\end{array}$ & NS & 10 & 0 \\
\hline Luxembourg & $30 / 4 / 2020$ & NS & $\begin{array}{c}1 \text { patient (pt) positive; } 2 \text { pts } \\
\text { negative, but with signs } \\
\text { of infection }\end{array}$ & NS & 5 & NS \\
\hline Portugal & $4 / 5 / 2020$ & $13 \mathrm{yrs}$ & Positive & NS & 1 & 0 \\
\hline Spain & $10 / 5 / 2020$ & 6.6 (6-13 mos.) & $\begin{array}{c}71 \% \text { of the pts tested } \\
\text { positive }\end{array}$ & $\begin{array}{l}\text { hMPV; Staph. } \\
\text { epidermidis; } \\
\text { rhinovirus }\end{array}$ & 22 & \\
\hline Sweden & $12 / 5 / 2020$ & $<12$ yrs & $\begin{array}{c}2 \text { pts positive and } \\
1 \text { pt negative }\end{array}$ & KLD & 3 & 0 \\
\hline Switzerland & $1 / 5 / 2020$ & NS & NS & NS & 3 & NS \\
\hline United Kingdom & $27 / 4 / 2020$ & NS & NS & NS & NS & NS \\
\hline United Kingdom & $6 / 5 / 2020$ & 8 (4-14 yrs) & $\begin{array}{c}3 \text { pts negative; } 3 \text { pts } \\
\text { exposed and tested } \\
\text { negative; } 2 \text { pts confirmed } \\
\text { COVID-19 positive }\end{array}$ & $\begin{array}{c}\text { Adenovirus and } \\
\text { HERV }\end{array}$ & 8 & 1 \\
\hline United Kingdom & $8 / 5 / 2020$ & 11 (11 months- 17 yrs) & $\begin{array}{l}\text { 12/37 PCR positive, } \\
\text { 17/20 lgG positive, } \\
\text { 54\% had evidence of } \\
\text { COVID-19 infection }\end{array}$ & EBV, viraemia & 40 & 1 \\
\hline $\begin{array}{l}\text { United States of } \\
\text { America }\end{array}$ & $7 / 4 / 2020$ & 6 months & Positive & NS & 1 & \\
\hline $\begin{array}{l}\text { United States of } \\
\text { America } \\
\text { (New York State) }\end{array}$ & $10 / 5 / 2020$ & $2-15$ yrs & $\begin{array}{l}\text { A proportion tested } \\
\text { positive for COVID-19 }\end{array}$ & NS & 85 & $\begin{array}{c}3 \text { ( } 2 \\
\text { additional } \\
\text { deaths under } \\
\text { investigation) }\end{array}$ \\
\hline
\end{tabular}

EBV: Epstein-Barr virus; EU/EEA: European Union/European Economic Area; HERV: Human endogenous retrovirus; hMVP: Human metapneumovirus; IVIG: Intravenous immunoglobulin; KLD: Kawasaki-like disease; NS: Not specified; PIMS: Pediatric inflammatory multisystem syndrome; pt: Patient.

\section{CONCLUSION}

COVID-19 infection is more prominent among adults than adolescents 15 years of age during the early stages of the outbreak. Moreover, the proportion of confirmed cases among children was relatively small. Many regions of the world have launched detection campaigns based on the global spread of the virus. However, the number of infections has risen tremendously especially in these age groups because younger children cannot wear masks and have not taken any special preventive and control measures. Therefore, this should be given high attention. ${ }^{[4]}$ Children exhibit certain peculiarities and cannot clearly describe 
their health status or contact history, which has contributed to the severe challenges in close families, transmission, cross-infection, protection, diagnosis and treatment of this population. ${ }^{[47]}$

Children are most likely to be infected with COVID-19 in their households or through family members, especially during lockdowns when school closures and strict physical distancing have been implemented. With the lockdown measures being lifted alongside reopening of schools, clubs, and some public places after the first phase of the virus, it is interesting to see how it could be transmitted among children bearing in mind the social distancing, reduction of classroom sizes, where possible and other stringent measures that could be taken to generally curtail the impact on children. Few interventional treatments on COVID-19 are currently open to patients $\leq 18$ years old. ${ }^{[48]}$ However, some approved EU-led research actions (e.g., DIAMONDS and RECOVER projects) are underway.

These strategic measures adopted by the EU will no doubt go a long way in tackling pediatric COVID-19 infection and its PIMS association. Moreover, these could be useful hints for other regions to emulate in dealing with the challenges posed by infected pediatric patients.

\section{Disclosures}

Peer-review: Externally peer-reviewed.

Conflict of Interests: The authors declare no conflicts of interests.

Funding: No funding or sponsorship was received for this study.

Authorship Contributions: Concept - E.H., D.F.; Design - E.H., D.F.; Supervision - E.H., D.F.; Literature search - E.H., D.F.; Writing E.H., D.F.; Critical Review - E.H., D.F.

\section{REFERENCES}

1. Voice of America. Europe, Asia continue to wary re-opening. Available at: https://www.voanews.com/covid-19-pandemic/ europe-asia-continue-wary-re-opening. Accessed Jul 10, 2020.

2. WHO. Coronavirus disease (COVID-19) - Situation Report - 154. Available at: https://apps.who.int/iris/handle/10665/332853. Accessed Jul 10, 2020.

3. Rutgers University. Children face risk for severe complications and death from COVID-19. In Most of the children admitted to pediatric intensive care units had underlying conditions. Available at: https://www.sciencedaily.com/releases/2020/05/200511142153.htm. Accessed Jul 10, 2020.

4. Wei M, Yuan J, Liu Y, Fu T, Yu X, Zhang ZJ. Novel Coronavirus Infection in Hospitalized Infants Under 1 Year of Age in China. JAMA 2020;323(13):1313-4. [CrossRef]

5. WHO. Report of the WHO-China joint mission on coronavirus disease 2019 (COVID-19). Available at: https://www.who.int/ publications/i/item/report-of-the-who-china-joint-missionon-coronavirus-disease-2019-(covid-19). Accessed Jul 10, 2020.

6. Medicaid.gov. Telemedicine. Centers for Medicare \& Medicaid Services. Baltimore; 2020. Available at: https://www.medicaid. gov/medicaid/benefits/telemedicine/index.html. Acccessed Jul 10, 2020.

7. Barney A, Buckelew S, Mesheriakova V, Raymond-Flesch M. The COVID-19 pandemic and rapid implementation of adolescent and young adult telemedicine: challenges and opportunities for innovation. J Adolesc Health 2020;67(2):164-71.

8. Chen S, Huang B, Luo DJ, Li X, Yang F, Zhao Y, et al. Pregnancy with new coronavirus infection: clinical characteristics and placental pathological analysis of three cases. Zhonghua Bing Li Xue Za Zhi 2020;49(5):418-23.

9. Karimi-Zarchi M, Neamatzadeh $H$, Dastgheib SA, Abbasi $H$, Mirjalili SR, Behforouz A, et al. Vertical Transmission of Coronavirus Disease 19 (COVID-19) from Infected Pregnant Mothers to Neonates: A Review. Fetal Pediatr Pathol 2020;39(3):24650. [CrossRef]

10. Chan JF, Yuan S, Kok KH, To KK, Chu H, Yang J, et al. A familial cluster of pneumonia associated with the 2019 novel coronavirus indicating person-to-person transmission: A study of a family cluster. Lancet 2020;395(10226):514-23. [CrossRef]

11. Bai Y, Yao L, Wei T, Tian F, Jin DY, Chen L, et al. Presumed asymptomatic carrier transmission of COVID-19. JAMA 2020;323(14):1406-7. [CrossRef]

12. Chen H, Guo J, Wang C, Luo F, Yu X, Zhang W, et al. Clinical characteristics and intrauterine vertical transmission potential of COVID-19 infection in nine pregnant women: A retrospective review of medical records. Lancet 2020;395(10226):809-15.

13. Li Y, Zhao R, Zheng S, Chen X, Wang J, Sheng X, et al. Lack of vertical transmission of severe acute respiratory syndrome coronavirus 2, China. Emerg Infect Dis 2020;26(6):1335-6. [CrossRef]

14. Liu D, Li L, Wu X, Zheng D, Wang J, Yang L, et al. Pregnancy and perinatal outcomes of women with coronavirus disease (COVID-19) pneumonia: a preliminary analysis. AJR Am J Roentgenol 2020;215(1):127-32. [CrossRef]

15. Zeng L, Xia S, Yuan W, Yan K, Xiao F, Shao J, et al. Neonatal early-onset infection with SARS-CoV-2 in 33 neonates born to mothers with COVID-19 in Wuhan, China. JAMA Pediatr 2020;174(7):722-5. [CrossRef]

16. Schwartz DA. An analysis of 38 pregnant women with COVID-19, their newborn infants, and maternal-fetal transmission of SARS-CoV-2: maternal coronavirus infections and pregnancy outcomes. Arch Pathol Lab Med 2020;144(7):799-805. [CrossRef]

17. Wolfel R, Corman VM, Guggemos W, Seilmaier M, Zange S, Muller MA, et al. Virological assessment of hospitalized patients with COVID-2019. Nature 2020;581(7809):465-9. [CrossRef]

18. To KK, Tsang OT, Leung WS, Tam AR, Wu TC, Lung DC, et al. 
Temporal profiles of viral load in posterior oropharyngeal saliva samples and serum antibody responses during infection by SARS-CoV-2: an observational cohort study. Lancet Infect Dis 2020;20(5):565-74. [CrossRef]

19. Jiehao C, Jin X, Daojiong L, Zhi Y, Lei X, Zhenghai Q, Yet al. A case series of children with 2019 novel coronavirus infection: clinical and epidemiological features. Clin Infect Dis 2020;71(6):1547-51. [CrossRef]

20. Young BE, Ong SWX, Kalimuddin S, Low JG, Tan SY, Loh J, et al; Singapore 2019 Novel Coronavirus Outbreak Research Team. Epidemiologic features and clinical course of patients infected with SARS-CoV-2 in Singapore. JAMA 2020;323(15):1488-94.

21. Chang L, Yan Y, Wang L. Coronavirus disease 2019: coronaviruses and blood safety. Transfus Med Rev 2020;34(2):75-80.

22. Backer JA, Klinkenberg D, Wallinga J. Incubation period of 2019 novel coronavirus (2019-nCoV) infections among travellers from Wuhan, China, 20-28 January 2020. Euro Surveill 2020;25(5):2000062. [CrossRef]

23. Zhou F, Yu T, Du R, Fan G, Liu Y, Liu Z, et al. Clinical course and risk factors for mortality of adult inpatients with COVID-19 in Wuhan, China: A retrospective cohort study. Lancet 2020;395(10229):1054-62. [CrossRef]

24. Peng L, Liu J, Xu W, Luo Q, Chen D, Lei Z, et al. SARS-CoV-2 can be detected in urine, blood, anal swabs, and oropharyngeal swabs specimens. J Med Virol 2020;92(9):1676-80. [CrossRef]

25. Lauer SA, Grantz KH, Bi Q, Jones FK, Zheng Q, Meredith HR, et al. The incubation period of coronavirus disease 2019 (COVID-19) from publicly reported confirmed cases: estimation and application. Ann Intern Med 2020;172(9):577-82. [CrossRef]

26. CDC COVID-19 Response Team. Coronavirus disease 2019 in children - United States, February 12-April 2, 2020. MMWR Morb Mortal Wkly Rep 2020;69(14):422-6. [CrossRef]

27. Ministry of Health, Labour and Welfare. About coronavirus disease 2019 (COVID-19). Tokyo; 2020. Available at: https://www. mhlw.go.jp/stf/seisakunitsuite/bunya/0000164708_00079. html. Accessed Jun 1, 2021.

28. Mizumoto K, Kagaya K, Zarebski A, Chowell G. Estimating the asymptomatic proportion of coronavirus disease 2019 (COVID-19) cases on board the Diamond Princess cruise ship, Yokohama, Japan, 2020. Euro Surveill 2020;25(10):2000180. [CrossRef]

29. Ki M, Task Force for -nCo V: Epidemiologic characteristics of early cases with 2019 novel coronavirus (2019-nCoV) disease in Korea. Epidemiol Health 2020;42:e2020007. [CrossRef]

30. Epidemiology working group for ncip epidemic response ccfdc, prevention. The epidemiological characteristics of an outbreak of 2019 novel coronavirus diseases (COVID-19) in China. Zhonghua Liu Xing Bing Xue Za Zhi 2020;41(2):145-51.

31. Cereda D, Tirani M, Rovida F, Demicheli V, Ajelli M, Poletti P, et al. The early phases of the COVID-19 outbreak in Lombardy, Italy. Available at: https://arxiv.org/abs/2003.09320. Accessed Jun 1, 2021.
32. Mallineni SK, Innes NP, Raggio DP, Araujo MP, Robertson MD, Jayaraman J. Coronavirus disease (COVID-19): Characteristics in children and considerations for dentists providing their care. Int J Paediatr Dent 2020;30(3):245-50. [CrossRef]

33. Forbes MB, Mehta K, Kumar K, Lu J, Saux NL, Sampson M, et al. COVID-19 infection in children: Estimating pediatric morbidity and mortality. medRxiv. 2020 May 8. Doi: https://doi.org/1 0.1101/2020.05.05.20091751. [Epub ahead of print]. [CrossRef]

34. Mei S, Yu J, He B, Li J. Psychological investigation of university students in a university in Jilin province. Med Soc (Berkeley) 2011;24(5):84-6.

35. Cao W, Fang Z, Hou G, Han M, Xu X, Dong J, et al. The psychological impact of the COVID-19 epidemic on college students in China. Psychiatry Res 2020;287:112934. [CrossRef]

36. Sharma V, Reina Ortiz M, Sharma N. Risk and protective factors for adolescent and young adult mental health within the context of COVID-19: a perspective from Nepal. J Adolesc Health 2020;67(1):135-7. [CrossRef]

37. Saikarthik J, Saraswathi I, Siva T. Risk factors and protective factors of mental health during COVID-19 outbreak and lockdown in adult Indian population - A cross-sectional study. MedRxiv. 2020 Jul 3. Doi: https://doi.org/10.1101/2020.06.13 .20130153. [Epub ahead of print]. [CrossRef]

38. Ghosh R, Dubey MJ, Chatterjee S, Dubey S. Impact of COVID-19 on children: Special focus on the psychosocial aspect. Minerva Pediatr 2020;72(3):226-35. [CrossRef]

39. Becker SP, Gregory AM. Editorial perspective: perils and promise for child and adolescent sleep and associated psychopathology during the COVID-19 pandemic. J Child Psychol Psychiatry 2020;61(7):757-9. [CrossRef]

40. Yoshikawa H, Wuermli AJ, Britto PR, Dreyer B, Leckman JF, Lye SJ, et al. Effects of the global coronavirus disease-2019 pandemic on early childhood development: Short- and long-term risks and mitigating program and policy actions. J Pediatr 2020;223:188-93. [CrossRef]

41. Courage KH. What we know about the new Covid-19-linked illness in children. In a rare, Kawasaki-like disease is striking kids who have coronavirus antibodies. Available at: https:// www.vox.com/2020/5/13/21257568/kids-covid-19-kawasakipediatric-multisymptom-inflammatory-disease. Accessed Jun 1, 2021.

42. European Centre for Disease Prevention and Control. Rapid risk assessment: Paediatric inflammatory multisystem syndrome and SARS-CoV-2 infection in children. Available at: https://www.ecdc.europa.eu/en/publications-data/paediatric-inflammatory-multisystem-syndrome-and-sars-cov-2-rapid-risk-assessment. Accessed Jun 1, 2021.

43. Verdoni L, Mazza A, Gervasoni A, Martelli L, Ruggeri M, Ciuffreda $M$, et al. An outbreak of severe Kawasaki-like disease at the Italian epicentre of the SARS-CoV-2 epidemic: An observational cohort study. Lancet 2020;395(10239):1771-8. [CrossRef] 
44. Riphagen S, Gomez X, Gonzalez-Martinez C, Wilkinson N, Theocharis P. Hyperinflammatory shock in children during $\mathrm{CO}-$ VID-19 pandemic. Lancet 2020;395(10237):1607-8. [CrossRef]

45. Galeotti C, Bayry J. Autoimmune and inflammatory diseases following COVID-19. Nat Rev Rheumatol 2020;16(8):413-4.

46. Toubiana J, Poirault C, Corsia A, Bajolle F, Fourgeaud J, Angoulvant $F$, et al. Outbreak of Kawasaki disease in children during COVID-19 pandemic: A prospective observational study in Paris, France. medRxiv. 2020 May 14. doi: https://doi.org/10.1 101/2020.05.10.20097394. [Epub ahead of print]. [CrossRef]
47. Lifen Y, Zhenyuan D, Mengqi D, Yang Z, Wanqiu D, Li P, et al. Advice on pediatric medical staff in the treatment of 2019 new coronavirus infection pneumonia. New Med 2020;51(2):7784.

48. Daskalakis DC. 2020 Health Alert \#13: Pediatric multi-system inflammatory syndrome potentially associated with COVID-19. New York City Health Department; 2020. Available at: https://www1.nyc.gov/assets/doh/downloads/pdf/han/ alert/2020/covid-19-pediatric-multi-system-inflammatorysyndrome.pdf. Accessed May 4, 2020. 